\title{
Isolasi dan Aktivitas Fermentasi Bakteri Asam Asetat pada Nira Nipah (Nypa fruticans)
}

\author{
Laili Fitri Yeni, Adi Hidayat, dan Reni Marlina \\ Pendidikan Biologi, FKIP Universitas Tanjungpura
}

\begin{abstract}
Abstrak
Penelitian tentang isolasi dan aktivitas fermentasi bakteri asam asetat pada nira nipah (Nypa fruticans) bertujuan menentukan jenis dan karakterisasi dari bakteri asam asetat sampai tingkat genus. Isolasi dilakukan menggunakan media spesifik Pepton - Yeast ekstrak - Glukosa + Etanol untuk mengamati jenis bakteri yang berperan dalam aktivitas fermentasi. Identifikasi menggunakan metode standar dari Bergey's Manual Determinative of Bacteriology. Diperoleh 6 isolat bakteri asam asetat yang berperan dalam fermentasi nira nipah. isolat yang tumbuh tergolong genus Acetobacter. Dari aktivitas bakteri dalam proses fermentasi nira nipah menjadi asam asetat, diketahui $\mathrm{pH}$ maksimal (derajat keasaman) cuka nipah adalah 2-3. Nilai kandungan asam yang dihasilkan dalam fermentasi $25 \mathrm{ml}$ adalah sebesar 9,36\%, dengan kandungan alkohol yang terbentuk sebanyak $24,8 \%$.
\end{abstract}

Kata kunci : isolasi, fermentasi, bakteri asam asetat

\section{Pendahuluan}

Nipah (Nypa fruticans) merupakan sejenis palem (palma) yang tumbuh di lingkungan hutan bakau atau daerah pasang surut dekat tepi laut. Indonesia memiliki areal hutan nipah yang cukup luas. Diperkirakan sekitar $17 \%$ dari areal hutan nipah dunia yang luasnya mencapai 35.000.000 hektar berada di Indonesia. Hutan nipah tersebut tersebar di Kalimantan, Sumatra, Sulawesi, Maluku dan Irian Jaya (Widjanarko, 2008).

Pohon nipah sebagai salah satu komponen ekosistem hutan mangrove $(30 \%$ terdapat di Pulau Kalimantan) mempunyai manfaat yang cukup besar bagi kehidupan masyarakat. Namun hingga saat ini, pemanfaatan pohon nipah baru terbatas pada pemanfaatan daun tua sebagai bahan atap rumah sedangkan daun muda dibuat anyaman dan digunakan sebagai dinding yang oleh masyarakat sekitar disebut "kajang". Di beberapa daerah tertentu nira nipah dijadikan sebagai bahan baku gula. Sayang, belakangan ada usaha pengrusakan hutan nipah ini, terutama di wilayah $\mathrm{HPH}$.

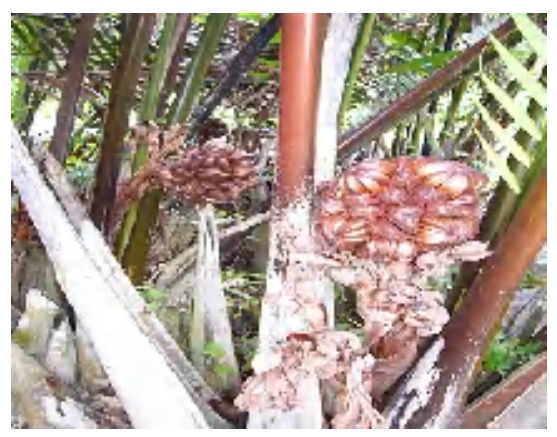

Gambar 1. Tanaman Nipah 
Observasi lapangan (Januari 2009), menemukan di daerah pesisir Kalimantan Barat masih banyak dijumpai populasi hutan nipah. Diantaranya adalah daerah sepanjang pesisir Mempawah (desa Sungai Bakau), Mempawah Hilir, kabupaten Sambas, kabupaten Kayong Utara dan kecamatan Sungai Kakap. Penduduk di daerah Mempawah dan kecamatan Sungai Kakap sangat jarang memanfaatkan nira nipah.

Tanaman nipah yang berumur 5 tahun ke atas bisa disadap untuk mendapatkan nira. Nira merupakan cairan manis yang diperoleh dari tandan bunga yang belum mekar. Kadar air nira segar sebesar $80-85 \%$ dan sukrosa sekitar 15\% (Goutara dan Wujudi dalam Manjilala, 2007). Keadaan tersebut sangat cocok untuk pertumbuhan mikroorganisme. Mikroba yang terdapat pada nira adalah khamir dan bakteri (Muchtadi dalam Manjilala, 2007). Dalam keadaan aerob, bakteri tersebut sangat berperan dalam proses fermentasi.

Secara mikrobiologis, bila alkohol dibiarkan terpapar udara maka akan berubah menjadi asam. Asam cuka timbul dari hasil kegiatan bakteri Acetobacter. Bakteri tersebut bersifat aerob, untuk mendapatkan energi mikroba menggunakan glukosa atau zat organik yang lain sebagai substrat untuk dioksidasi menjadi karbondioksida dan air (Waluyo, 2007). Metabolisme bakteri Acetobacter yang bersifat aerobik mempunyai fungsi yang sangat penting, karena mempunyai kemampuan untuk mengoksidasi alkohol dan karbohidrat lainnya menjadi asam asetat.
Mekanisme fermentasi pada pembuatan asam asetat dibagi menjadi dua, yaitu fermentasi alkohol dan fermentasi asam asetat. Pada fermentasi alkohol, mula-mula gula yang terdapat pada bahan baku diubah menjadi alkohol dan $\mathrm{CO}_{2}$ yang berlangsung secara anaerob. Setelah alkohol dihasilkan, segera dilakukan fermentasi asam asetat. Bakteri asam asetat mengubah alkohol menjadi asam asetat secara aerob. Setelah terbentuk asam asetat fermentasi harus segera dihentikan supaya tidak terjadi fermentasi lebih lanjut oleh bakteri pembusuk yang dapat menimbulkan kerusakan (Hidayat dkk, 2006).

Penelitian ini diarahkan untuk melihat jenis bakteri yang berperan dalam proses fermentasi nira nipah. Isolasi bakteri dilakukan untuk mendapatkan isolat bakteri yang berperan dalam proses fermentasi asam asetat dan untuk mempelajari bentuk koloni, warna koloni, bentuk sel bakteri, sifat gram, dan sifat biokimia dari bakteri tersebut. Selain itu pada penelitian ini juga akan dilihat pembentukan asam asetat (asam cuka) oleh bakteri Acetobacter sebagai produk proses fermentasi dari nira nipah. Ada dua masalah yang akan dijawab dalam penelitian ini, yaitu :
1. Bagaimana karakterisasi bakteri asam asetat yang diisolasi dari nira nipah ( $\mathrm{Nypa}$ fruticans)?
2. Bagaimana aktivitas bakteri dalam proses fermentasi asam asetat dari nira nipah (Nypa fruticans)? 


\section{Metode Penelitian}

\section{A. Alat Dan Bahan Penelitian}

Beberapa alat yang digunakan adalah : Autoclave, inkubator, lemari pendingin, cawan petri, tabung reaksi, rak tabung reaksi, bunsen, gelas kimia, erlenmeyer, kertas label, timbangan analitik, pipet ukur, jarum ose, botol semprot, toples, magnetik stirrer, gelas objek, gelas penutup, pinset, mikroskop, dan tempat fermentasi.

Bahan habis pakai dalam penelitian ini adalah: Nira Nipah (Nypa fruticans); Media PYG (Pepton-Yeast ekstrak-Glukosa) padat yaitu dengan komposisi per liternya mengandung $5 \mathrm{~g}$ pepton, $5 \mathrm{~g}$ yeast ekstrak, 3 g glukosa, 15 g agar, $5 \mathrm{~g}$ kalsium karbonat, $30 \mathrm{ml}$ etanol $96 \%$ dan aquades sebanyak satu liter; Larutan Hucker kristal violet; Larutan mordar lugol's Iodin; Larutan Alkohol aseton; Larutan Safranin

\section{B. Prosedur Penelitian}

Pengambilan nira dilakukan pada bagian batang bunga yang belum mekar. Tandan nipah yang siap untuk disadap ditandai dengan mulai hilangnya bintik hitam runcing pada buah. Penyadapan diawali penyiraman tandan dengan air, dilanjutkan dengan pemotongan tandan dari bagian bawah tepatnya pada buku ke-1 bagian ujung dekat tandan. Setelah itu diikatkan kantong plastik (ukuran 1 kg) untuk menampung nira.

Setelah nira tertampung, dibawa ke laboratorium untuk disaring dan dimasukkan ke dalam toples kaca bertutup rapat dan didiamkan selama 3 hari di tempat yang suhunya konstan, agar bakteri dapat berkembang.

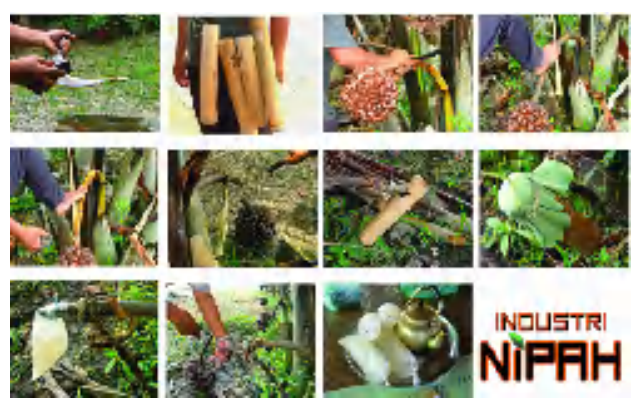

Gambar 2. Proses pengambilan nira nipah. Sumber: Yayasan Pembangunan Usahawan Terengganu (YPU)

Isolasi bakteri asam asetat dari nipah dilakukan dengan metode teknik kultur diperkaya. Bakteri dari nira nipah diperoleh dengan mengambil $1 \mathrm{ml}$ nira yang telah didiamkan selama 3 hari, kemudian air nira tersebut dimasukkan dalam 9 $\mathrm{ml}$ aquades dan dihomogenkan. Selanjutnya dilakukan pengenceran sampai $10^{-5}$. Masing-masing seri pengenceran diambil $1 \mathrm{ml}$ dan dilakukan dengan metode pour plate pada media agar Pepton-Yeast Extract-Glucose (PYG). Selanjutnya, diinkubasi pada suhu $27^{0} \mathrm{C}$ selama 24-48 jam. Isolat yang tumbuh pada cawan petri, koloninya (tipe, ukuran dan bentuk) dipindahkan untuk dimurnikan dengan goresan pada media yang sama.

Identifikasi bakteri asam asetat dilakukan menggunakan metode standar dari Bergey's Manual Determinative of Bacteriology (Holt dkk, 1994), yang meliputi karakterisasi morfologi dan biokimia bakteri. Morfologi bakteri diamati berdasarkan pengamatan morfologi koloni dan morfologi sel. Morfologi koloni yang diamati meliputi bentuk, elevasi, tepi dan warna dan 
morfologi sel berdasarkan hasil pengecatan gram yang meliputi bentuk sel dan sifat gram. Uji fisiologis dilakukan dengan melihat pengaruh suhu terhadap pertumbuhan bakteri asam asetat. Suhu yang digunakan adalah $20^{\circ}$, $27^{\circ}, 37^{\circ}$, dan $50^{\circ}$.

Sifat Biokimia ditentukan dengan melakukan uji katalase dengan cara mengambil satu ose isolat yang telah dimurnikan, kemudian dioleskan pada gelas benda yang telah diberi alkohol. Gelas benda ditetesi dengan larutan $\mathrm{H}_{2} \mathrm{O}_{2} \quad 3 \%$. Diamati terbentuknya gelembung gas pada preparat. Jika terdapat gelembung gas berarti uji katalase tersebut positif (Lay, 1994).

Pembuatan cuka mengikuti diagram berikut ini :

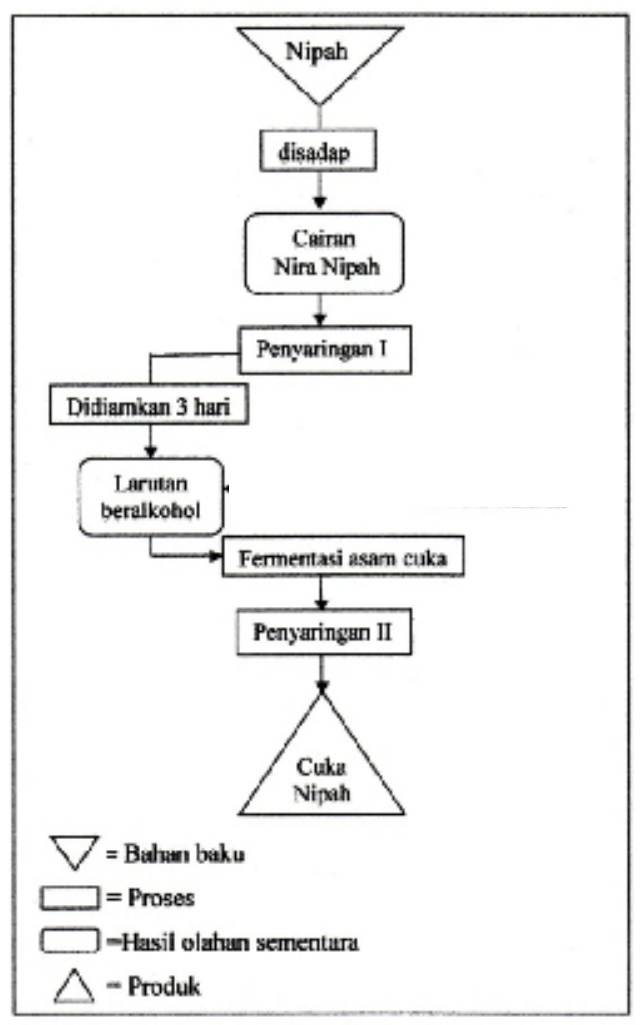

Diagram 1 : Skema Pembuatan Cuka Nipah Sumber editan: Santoso (1995).
Larutan asam cuka yang telah terfermentasi selanjutnya diamati perubahan yang terbentuk. Parameter yang di amati meliputi: $\mathrm{pH}$ larutan, total asam dan kadar alkohol. $\mathrm{pH}$ larutan atau tingkat keasaman diukur dengan menggunakan alat $\mathrm{pH}$ meter. Pengukuran ini dilakukan selama proses fermentasi berlangsung. Perhitungan total asam dilakukan dengan mengambil $5 \mathrm{ml}$ sampel kemudian diencerkan sampai $25 \mathrm{ml}$ kemudian ditambahkan 2-3 tetes pp. Selanjutnya dititrasi dengan $\mathrm{NaOH}$ $0,01 \mathrm{~N}$ hingga berwarna jingga. Selanjutnya volume titran dihitung menggunakan rumus:

Total asam :

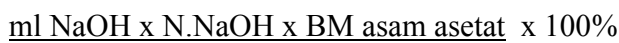
ml sampel

Untuk mengukur kadar alkohol yang terkandung didalam larutan diambil $25 \mathrm{ml}$ larutan kemudian dilakukan destilasi. kemudian dari proses destilasi dapat diketahui jumlah alkohol yang terkandung.

\section{Hasil dan Pembahasan Hasil}

\section{Karakterisasi Bakteri}

Diperoleh 6 isolat bakteri yang berperan dalam fermentasi nira nipah menjadi asam asetat. Isolat bakteri yang diperoleh ditandai dengan terlihatnya koloni bakteri yang tumbuh pada media PYG yang diinkubasi selama 24 jam. Metode standar dari Bergey's Manual Determinative of Bacteriology (Holt dkk, 1994) digunakan untuk mengidentifikasi koloni bakteri. Hasilnya disajikan pada Tabel 1 . 
Tabel 1. Karakterisasi Morfologi Bakteri yang Berperan dalam Fermentasi nira nipah menjadi asam asetat.

\begin{tabular}{|l|c|c|c|c|c|c|}
\hline \multirow{2}{*}{ Karakter } & \multicolumn{6}{|c|}{ Isolat } \\
\cline { 2 - 7 } & I & II & III & IV & V & VI \\
\hline 1. Morfologi koloni & \multicolumn{7}{|c|}{ Krem } \\
\hline a. Warna & Krem & Putih & Putih & Putih & Putih & $\begin{array}{c}\text { Kransparan } \\
\text { Trat }\end{array}$ \\
\hline b. Bentuk & Bulat & Bulat & Bulat & Bulat & Bulat & Bulat \\
\hline c. Elevasi & Cembung & Timbul & Tombol & Tombol & Tombol & Timbul \\
\hline d. Tepian & Licin & Licin & Licin & Tak beraturan & Berombak & Licin \\
\hline 2. Morfologi sel & \multicolumn{7}{|c|}{} \\
\hline a. Bentuk sel & Batang & Batang & Batang & Batang & Batang & Batang \\
\hline b. Sifat Gram & Negatif & Negatif & Negatif & Negatif & Negatif & Negatif \\
\hline
\end{tabular}

Tabel 1 menunjukkan ciri morfologi koloni yang berbeda. Namun, terdapat persamaan morfologi yang dimiliki oleh semua isolat yaitu bentuk koloni yang berbentuk bulat/bundar. Pengamatan morfologi koloni bakteri dapat dilihat setelah mengisolasi bakteri ke dalam cawan petri dengan metode taburan (pour plate method). Hasil isolasi enam isolat bakteri dapat dilihat pada gambar 3 .
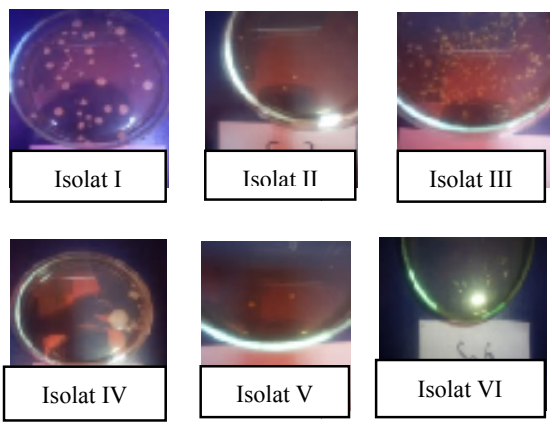

Gambar 3. Isolat Bakteri yang Diisolasi dari Nira Nipah

Selain pengamatan morfologi koloni, juga dilakukan pengamatan mikroskopis untuk melihat morfologi sel bakteri dan sifat gram. Dari pengamatan mikroskopis diketahui bahwa semua isolat memiliki bentuk sel yang sama yaitu bentuk batang

(basil) dan memiliki sifat gram negatif (Gambar 4)

Isolat I

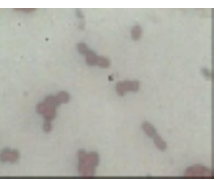

Isolat II

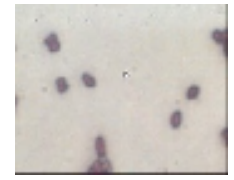

Isolat III

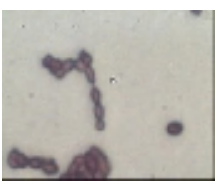

Gambar 4. Hasil Pengamatan Pewarnaan Bakteri Asam Asetat yang Diisolasi dari Nira Nipah (perbesaran 100x)

Gambar 4 menunjukkan keenam isolat merupakan satu genus, karena memiliki ciri morfologi sel yang sama. Uji fisiologis dilakukan dengan melihat pengaruh suhu terhadap pertumbuhan bakteri asam asetat. Uji ini bertujuan untuk menggolongkan bakteri tersebut 
termasuk psikhrofil, mesofil, termofil atau hipertermofil. Uji biokimia yang dilakukan adalah uji katalase, uji ini bertujuan melihat bakteri tersebut menghasilkan enzim katalase atau tidak. Hasilnya disajikan pada Tabel 2.

Tabel 2. Hasil Uji Fisiologis dan Biokimia Bakteri Asam Asetat yang Diisolasi dari Nira Nipah

\begin{tabular}{|l|c|c|c|c|c|c|}
\hline \multirow{2}{*}{ Karakter } & \multicolumn{5}{c|}{ Isolat } \\
\cline { 2 - 7 } & I & II & III & IV & V & VI \\
\hline 1. Sifat fisiologis & & & & & & \\
\hline a. Tumbuh pada suhu & $20^{\circ}-37^{\circ}$ & $20^{\circ}-37^{\circ}$ & $20^{\circ}-37^{\circ}$ & $20^{\circ}-27^{\circ}$ & $20^{\circ}-37^{\circ}$ & $20^{\circ}-27^{\circ}$ \\
\hline 2. Sifat biokimia & & & & & & \\
\hline a. Katalase & Positif & Positif & Positif & Positif & Positif & Positif \\
\hline
\end{tabular}

Dari pengamatan pengaruh suhu terhadap pertumbuhan bakteri, diketahui bahwa keenam isolat bakteri yang didapat tergolong bakteri mesofil. Bakteri mesofil berarti bakteri tersebut tumbuh pada kisaran suhu antara $20^{\circ}-45^{\circ} \mathrm{C}$. Sedangkan dari hasil uji biokimia menunjukkan keenam isolat bakteri tersebut memiliki enzim katalase yang ditandai dengan terbentuknya gelembung gas pada saat uji katalase.

\section{Aktivitas Bakteri dalam Proses Fermentasi Asam Asetat dari Nira Nipah (Nypa fruticans)}

Sebelum aktivitas fermentasi dimulai, nira nipah disaring terlebih dahulu untuk menghilangkan kontaminan/kotoran yang dapat mengganggu proses fermentasi. Kemudian diukur pH (derajat keasaman) dari nira, selanjutnya nira disimpan dalam lemari bersih dan memiliki sirkulasi udara yang baik, selama proses fermentasi $\mathrm{pH}$ nira selalu diukur sampai $\mathrm{pH}$ nira tersebut konstan. Aspek yang diamati untuk melihat aktivitas bakteri selama proses fermentasi pada nira adalah $\mathrm{pH}$ (derajat keasaman), pengukuran kadar alkohol dan total asam yang terkandung dalam larutan hasil fermentasi. Untuk hasil pengukuran $\mathrm{pH}$ dapat dilihat pada tabel 3 .

Tabel 3. Hasil Pengukuran pH Hasil Fermentasi Asam Asetat

\begin{tabular}{|c|c|c|}
\hline No. & $\begin{array}{c}\text { Fermentasi } \\
\text { hari ke- }\end{array}$ & $\mathrm{pH}$ \\
\hline 1. & 1 & $4-5$ \\
\hline 2. & 2 & $4-5$ \\
\hline 3. & 3 & $3-4$ \\
\hline 4. & 4 & $3-4$ \\
\hline 5. & 5 & $3-4$ \\
\hline 6. & 6 & $2-3$ \\
\hline
\end{tabular}

Hasil pengukuran $\mathrm{pH}$ asam asetat menunjukkan penurunan $\mathrm{pH}$ selama 6 hari fermentasi. Penurunan $\mathrm{pH}$ berlangsung secara bertahap dari rentang 4-5 pada hari pertama sampai rentang 2-3 pada hari ke enam.

Setelah hari ke-6, dilakukan pengukuran kadar alkohol dan perhitungan total asam yang terdapat pada produk fermentasi. Pengukuran kadar alkohol dilakukan dengan proses destilasi pada suhu $80^{\circ} \mathrm{C}$ dan larutan yang digunakan sebanyak 25 ml. Sedangkan, perhitungan total asam menggunakan proses titrasi $\mathrm{NaOH}$ dengan menggunakan indikator pp. Hasil pengukuran kadar alkohol dan total asam hasil fermentasi dapat dilihat pada tabel 4 . 
Tabel 4. Hasil Pengukuran Kadar Alkohol dan Total Asam

\begin{tabular}{|l|c|}
\hline \multicolumn{1}{|c|}{ Pengukuran } & Persentase \\
\hline Pengukuran kadar alkohol & $24,8 \%$ \\
\hline Pengukuran total asam & $9,36 \%$ \\
\hline
\end{tabular}

\section{B. Pembahasan}

\section{Karakterisasi Bakteri Asam Asetat yang Diisolasi dari Nira Nipah (Nypa fruticans)}

\section{Diperoleh enam isolat bakteri yang berperan dalam proses} fermentasi nira nipah. Ciri khas keenam bakteri ini mampu tumbuh pada media Pepton-Yeast ekstrakglukosa (PYG) yang telah ditambahkan Etanol 90\% sebanyak 30 ml. Media PYG+etanol merupakan media spesifik bagi bakteri, bakteri yang dapat tumbuh pada media tersebut merupakan jenis bakteri asam asetat. Menurut Kozaki (1998), "Bakteri asam asetat mendapatkan energi dari oksidasi etanol". Oleh karena itu, jenis bakteri asam asetat mampu tumbuh pada media+etanol, sebab bakteri ini mendapatkan energi dari hasil oksidasi etanol tersebut.

Morfologi koloni keenam isolat tersebut adalah bulat. Sedangkan warna koloni didominasi oleh warna putih dan hanya satu yang transparan yaitu pada isolat VI. Untuk tipe tepian koloni bakteri diketahui isolat I sampai III memiliki tepian licin sedangkan pada isolat lainnya memiliki tepian berombak dan tidak beraturan. Pengamatan elevasi koloni ditemukan 3 tipe elevasi yang muncul yaitu cembung, timbul dan seperti tombol. Pengamatan mikroskopis bertujuan untuk melihat morfologi sel bakteri diketahui bahwa isolat I sampai VI memiliki bentuk sel basil (batang) dan bersifat gram negatif.

Menurut Williams dan Cannon (1989), bakteri asam asetat memiliki ciri bakteri gram negatif dan selselnya berbentuk basil atau batang. Karena keenam isolat yang ditemukan memilki ciri gram negatif dan memilki sel berbentuk batang, maka keenam isolat tersebut digolongkan kedalam kelompok bakteri asam asetat.

Uji sifat fisiologis bakteri menunjukkan bahwa keenam isolat yang tumbuh tergolong ke dalam kelompok bakteri mesofil, karena bakteri yang ditemukan tumbuh optimum pada suhu $27^{\circ} \mathrm{C}$. Hal ini mengacu pada pendapat Jay (1992) dan Hidayat dkk (2006) bahwa kelompok bakteri mesofil tumbuh pada suhu sedang, kisaran $20^{\circ}-45^{\circ} \mathrm{C}$ dan banyak terdapat pada tanah, air, serta tubuh vertebrata.

Uji sifat biokimia sel bakteri menunjukkan keenam isolat yang ditemukan merupakan katalase positif, hal ini ditandai dengan terbentuknya gelembung gas pada preparat setelah ditetesi dengan larutan $\mathrm{H}_{2} \mathrm{O}_{2} 3 \%$. Bakteri katalase positif artinya bakteri tersebut menghasilkan enzim katalase yang mampu memecah $\mathrm{H}_{2} \mathrm{O}_{2}$ menjadi air dan $\mathrm{O}_{2} . \mathrm{H}_{2} \mathrm{O}_{2}$ atau hydrogen peroksida merupakan racun yang dapat membunuh bakteri. Enzim katalase mampu memecah $\mathrm{H}_{2} \mathrm{O}_{2}$ menjadi air dan $\mathrm{O}_{2}$ sehingga sifat toksiknya hilang. Hal ini sesuai pernyataan William dan Cannon (1989) yang menyatakan bahwa karakteristik yang penting berkaitan dengan isolasi adalah morfologi sel (batang, gram negatif), memproduksi 
asam asetat dari etanol dengan adanya penjernihan pada agar $\mathrm{CaCO}_{3}$, dan katalase positif.

Hasil identifikas menunjukkan terdapat persamaan ciri-ciri isolat yang tumbuh dengan karakterisasi bakteri genus Acetobacter yang dapat dilihat pada Tabel 5.

Tabel 5. Persamaan ciri genus Acetobacter dengan isolat bakteri yang didapat (merujuk pada buku Bergey's Manual Determinative of Bacteriology).

\begin{tabular}{|l|c|c|c|c|c|c|c|}
\hline \multirow{2}{*}{ Karakter } & Genus Acetobacter & \multicolumn{7}{c|}{ Isolat } \\
\cline { 3 - 8 } & (Bergey,s) & I & II & III & IV & V & VI \\
\hline Bentuk sel & Basil & Basil & Basil & Basil & Basil & Basil & Basil \\
\hline Jenis Gram & - & - & - & - & - & - & - \\
\hline Keperluan Oksigen & + & + & + & + & + & + & + \\
\hline Glukosa & + & + & + & + & + & + & + \\
\hline H2S* & + & + & + & + & + & + & + \\
\hline Laktosa* & $+/-$ & - & - & - & - & - & - \\
\hline Motilitas & $+/-$ & + & + & + & + & + & + \\
\hline Katalse & + & + & + & + & + & + & + \\
\hline Oksidase* & - & - & - & - & - & - & - \\
\hline Suhu pertumbuhan & $25^{\circ}-30^{\circ} \mathrm{C}$ & $27^{\circ}$ & $27^{\circ}$ & $27^{\circ}$ & $27^{\circ}$ & $27^{\circ}$ & $27^{\circ}$ \\
\hline
\end{tabular}

Ket. * = Hasil penelitian Ira Erdiandini (2009).

Setelah dilakukan identifikasi terhadap isolat bakteri berdasarkan karakteristik morfologi, uji biokimia dan uji fisiologis (Tabel 1 dan 2) keenam isolat memiliki ciri-ciri bakteri dari genus Acetobacter. Proses identifikasi dari isolat merujuk pada buku Bergey's Manual Determinative of Bacteriology.

Hasil pengamatan morfologi koloni, uji fisiologis dan biokimia yang dilakukan, menunjukkan isolat yang tumbuh memiliki karakteristik bentuk koloni bulat, warna dominan putih dan bersifat motil. Pertumbuhannya memerlukan oksigen dan memerlukan glukosa. Sedangkan bentuk sel bakteri batang (basil), gram negatif dan katalse positif. Berdasarkan hasil di atas dapat disimpulkan bahwa isolat tersebut tergolong dalam genus Acetobacter. Dalam buku Bergey's dituliskan bahwa genus Acetobacter memilki bentuk sel batang, gram negatif, memerlukan oksigen dan glukosa, motil, serta menghasilkan enzim katalase. Selain itu, menurut William dan Cannon (1989) "Bakteri asam asetat sel-selnya berbentuk batang, gram negatif dan bersifat obligat aerob".

\section{Aktivitas Bakteri dalam Proses Fermentasi Asam Asetat dari Nira Nipah (Nypa fruticans)}

Selain dilakukan identifikasi bakteri pada fermentasi nira nipah (Nypa fruticans) juga dilakukan pengukuran $\mathrm{pH}$, pengukuran kadar alkohol, dan pengukuran total asam yang terkandung dalam hasil fermentasi nira nipah. Hasil pengukuran $\mathrm{pH}$ menunjukkan penurunan $\mathrm{pH}$ pada inkubasi selama 6 hari. Penurunan $\mathrm{pH}$ tidak berlangsung secara spontan, namun secara bertahap dari rentang 4-5 pada hari pertama inkubasi sampai rentang 2-3 pada hari ke-enam (Tabel 3). Hal ini mendukung dugaan bahwa isolat 
yang diperoleh adalah bakteri asam asetat, karena bakteri asam asetat dapat memproduksi asam asetat. Asam asetat yang terbentuk selama inkubasi inilah yang menyebabkan menurunnya nilai $\mathrm{pH}$ dari lingkungan pertumbuhannya.

Hasil pengukuran kadar alkohol dalam fermentasi nira nipah (Tabel 4), diperoleh kandungan alkohol sebanyak 24,8\%. Selanjutnya, alkohol yang terbentuk difermentasikan lebih lanjut untuk menghasilkan asam asetat. Hal ini sesuai dengan pernyataan Desrosier (1988), bahwa "Pembuatan cuka memerlukan dua proses fermentasi. Pertama, perubahan gula menjadi alkohol. Kedua, perubahan alkohol menjadi asam asetat dan dilakukan oleh bakteri asam cuka".

Hasil perhitungan total asam, diketahui bahwa asam yang terbentuk adalah sebanyak 9,36\% (Tabel 4). Pada umumnya, perubahan yang terjadi dari alkohol menjadi asam dapat ditunjukkan dengan persamaan berikut:

$\mathrm{C}_{2} \mathrm{H}_{5} \mathrm{OH}+\mathrm{O}_{2}+$ Acetobacter $\rightarrow \mathrm{CH}_{3} \mathrm{COOH}+\mathrm{H}_{2} \mathrm{O}$

Berdasarkan persamaan di atas diketahui bahwa pembentukan asam cuka pada fermentasi nira nipah yang dilakukan merupakan hasil dari oksidasi alkohol oleh bakteri Acetobacter dengan adanya oksigen dari udara. Bakteri Acetobacter ternyata memerlukan sediaan oksigen untuk pertumbuhan dan aktivitasnya. Sedangkan dari segi $\mathrm{pH}$ (derajat keasaman), hasil fermentasi memiliki nilai $\mathrm{pH}$ yang sama dengan asam cuka yang dijual dipasaran yaitu bernilai 3-2 (pengukuran menggunakan indikator universal).
Pengamatan lanjutan yang dilakukan, menunjukkan bahwa setelah fermentasi asetat selesai asam cuka tidak boleh dibiarkan terkena udara secara berlebihan karena dapat menurunkan kadar asamnya. Hasil pengamatan ini juga diperkuat oleh Desrosier (1988) yang menyatakan "Sesudah fermentasi asetat berjalan sempurna, cuka tidak boleh kontak dengan udara sebab cuka dapat teroksidasi lebih lanjut menjadi karbondioksida dan air, sehingga kadar asam menurun agak lebih cepat sampai pada suatu kondisi yang tidak dikehendaki. Untuk mengatasi hal ini cuka harus ditempatkan dalam kemasan yang tertutup rapat dan dengan isi yang penuh dan cuka dapat juga dipasteurisasi".

\section{Simpulan}

Enam isolat bakteri asam asetat yang berperan dalam fermentasi nira nipah (Nypa fruticans) yang tumbuh pada media spesifik PYG + Etanol tergolong genus Acetobacter. Aktivitas bakteri dalam proses fermentasi nira nipah menjadi asam asetat pada $\mathrm{pH}$ maksimal 2-3. Nilai kandungan asam yang dihasilkan dalam fermentasi $25 \mathrm{ml}$ adalah sebesar 9,36\%, dengan kandungan alkohol yang terbentuk sebanyak $24,8 \%$.

\section{Daftar Pustaka}

Desrosier, N.W. 1988. Teknologi Pengawetan Pangan

Penerjemah: Muchji

Mulijohardjo. Jakarta.

Universitas Indonesia Press. 
Hidayat, Nur., M, Padaga dan Sri Suhartini. 2006. Mikrobiologi Industri. Yogyakarta. ANDI.

Holt, G.Jhon, Noel, R.Krieg, Peter, H.A.Sneath, James, T.Staley, Stanley, T.Williams. 1994. Bergey's Manual Of Determinative Bacteriology, Ninth Edition. New York. Waverly Company.

Jay, J.M. 1992. Modern Food Microbiology, Fourth Edition. New York. Van Nostrand Reinhold.

Kozaki, M. Lino, H. Matsomoto, T. Dizon, E.I.Kuswanto, and P.C. Sanchez. 1998. Studies on the Acid Producing Bacteria of Traditional Vinegars from Philipines and Indonesia. Proceding of International Conference on Asian Network on Microbial Research. Yogyakarta. UGM.

Lay, B. W. 1994. Analisis Mikrobiologi di Laboratorium. (Terjemah). Jakarta. PT. Raja Grafindo Persada.
Manjilala. 2007. Pengaruh Pemberian Pengawet (kulit kesambi) pada saat penyadapan nira terhadap kualitas gula merah di kabupaten sidap. http: //Manjilala.blogster.com (Diakses tanggal: 15 januari 2009).

Santoso, Hieronymus. 1995. Teknologi Tepat Guna. Yogyakarta. Kanisius.

Waluyo, lud. 2007. Mikrobiologi Umum. Malang. UMM Press.

Widjanarko, S., 2008, Siwalan dan Kandungan Niranya, Artikel Ilmu Pengetahuan, http://www.simonbwidjanarko.w ordpress.com (22 September 2008).

Williams, W.S and R.E Cannon. 1989. Alternative Environmental Roles for Cellulose Produced by Acetobacter Xylinum. Applied and Environmental Microbiology. American Society for Microbiology. 
Isolasi dan Aktivitas Fermentasi (Laili F) 11 